\title{
観血的治療を行った外傷性股関節脱臼について
}

\author{
久留米大学医学部整形外科教室（主任：宮城成圭教授） \\ 金 沢 知 基 -中林 昭 策 \\ 加藤田 善 朗・樋 口 富士男 \\ 井上博
}

\section{Experiences of Fracture-Dislocation of the Hip Treated Surgically}

By

\author{
T. Kanazawa, S. Nakabayashi, Y. Katoda, \\ F. Higuchi and $\mathrm{H}$. Inoue \\ Department of Orthopedic Surgery, Kurume University School of \\ Medicine (Director: Prof. S. Miyagi, M. D.)
}

\begin{abstract}
Out of 22 cases of fracture-dislocation of the hip, 16 cases, including 13 posterior, 2 anterior and one central dislocation, were treated srgically for the past 5 years. Three dislozations were reduced within 48 hours and the remaining after 5 days or more, being on an average of 47 days.

While the satisfactory results were obtained in the former 3 cases, the results were entirely unsatisfactory in the remaining but one. The authors emphasized that the surgical interventions should be carried out as early as possible, if indicated.
\end{abstract}

はじめに

外傷性股関節脱臼骨折の治療は, 他の脱臼骨折に比 して, その損傷の多様性, 続発する二次性変形性股関 節症や a vascular necrosis の発生頻度からみても， 治療上に多くの問題を含んでいる.今回われわれは当 教室において最近 5 年間に経験した外傷性股関節脱臼 22 症例のうち何らかの観血的治療を行った 16 関節に つき検討したので報告する.

\section{症 例の概略}

男性 14 例, 女性 2 例で, 受傷時年令は最高 61 才, 最少 18 才, 平均 39 才であった. 受傷原因は交通事故 12 例, 労㗢災害 3 例, 体操によるもの 1 例で, 右側 11 例, 左側 5 例であった. 脱臼形は, 前方脱臼 2 例, 中心性脱臼 1 例であり, 後方脱臼 13 例については, 特に比較的よく引用されている Stewart の分類によ り, I IV Grade に分けて検討した. 即ち Grade I （骨折を伴なわない脱臼，または目蓋縁の小さな骨折
を伴なう脱臼）1例，Grade II（臼蓋縁の大きな骨 折を伴い, 整復後安定性の得られるあの) 2 例, Grade III (臼蓋縁の高度の破壊があり, 整復後不安 定性を残すむの） 3 例，Grade IV（大腿骨頭または 頸部骨折を伴うもの） 7 例であった，受傷から整復ま での期間は， 12 時間以内 2 例， 2 日目に整復された 1 例, 計 3 例は全て徒手整復例であり, 観血的整復術 では, 最短 5 日, 最長 7 力月であり, 平均 47 日であ った，当教室における観血的治療は，非観血的整復後 に何らかの観血的治療を行ったものでは，臼盖縁の骨 接合術 1 例, 骨片の剔出術 2 例, 観血的整復術のみ 4 例, 観血的整復術に毛蓋縁の骨接合術を行ったもの 1 例，臼蓋縁之頸部の骨接合術 1 例，骨頭之頸部の骨接 合術を行ったもの 1 例，骨片の剔出術を行なったもの 2 例であった. その他人工関節置換術 2 例, 骨切り術 1 例, 骨頭切除および骨切り術併用 1 例であった. 免 荷期間は最短 4 週間, 最長 6 力月間, 平均 13 週間で あった. 合併症として, 下腿骨折 5 例, 大腿骨折と下 腿骨折の合併 1 例, その他頭部外傷 3 例, 上腕骨折, 
表 $\quad 1$

\begin{tabular}{|c|c|c|c|c|c|c|c|}
\hline 症例 & $\begin{array}{l}\text { 年 } \\
\text { 令 }\end{array}$ & 性 & 分 類 & $\begin{array}{l}\text { 受佰より整 } \\
\text { 復までの期 } \\
\text { 間 }\end{array}$ & 免荷期間 & 観 血 的 治 療 & 総合判定 \\
\hline 1 & 52 & M & $\begin{array}{l}\text { 後方脱日 } \\
\text { III }\end{array}$ & 2 日 & 2 力月 & 日蓋縁骨接合術 & 良 \\
\hline 2 & 27 & M & $\begin{array}{c}\text { 後方脱白 } \\
\mathrm{NV}\end{array}$ & 11日 & 3 力月 & $\begin{array}{l}\text { 観血的慗復術 } \\
\text { 片捅出術 }\end{array}$ & 可 \\
\hline 3 & 22 & $\mathrm{~F}$ & $\begin{array}{c}\text { 後方 脱 } \\
\text { IV }\end{array}$ & 12時間 & 1 力月 & 骨片摘出術 & 優 \\
\hline 4 & 29 & M & 前方脱白 & 7 力月 & 1 力月 1 週 & 観血的整復術 & 不 可 \\
\hline 5 & 45 & M & 後方脱日 & 2 力月 & 4 力月 & 観血的整復術 & 不 可 \\
\hline 6 & 35 & M & 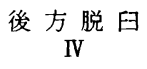 & 5 日 & 3 力月 & $\begin{array}{l}\text { 観血的整復術 } \\
\text { 顝部, 自接合術 }\end{array}$ & 可 \\
\hline 7 & 32 & M & 中心性脱臼 & 12 時間 & 3 力月 & 骨片摘出術 & 良 \\
\hline 8 & 29 & M & 前方脱臼 & 1 力月 2 週 & 1 力月 & 観血的整復術 & 良 \\
\hline 9 & 57 & M & $\begin{array}{c}\text { 後方脱 } \mathrm{E} \\
\text { II }\end{array}$ & 3 週 & 3 力月 & $\begin{array}{l}\text { 観血的慗復術 } \\
\text { 出術 }\end{array}$ & 可 \\
\hline 10 & 42 & M & $\begin{array}{c}\text { 後方脱白 } \\
\mathrm{IV}\end{array}$ & 8 日 & 6 力月 & $\begin{array}{l}\text { 観血的整復術 } \\
\text { 頭接合術 }\end{array}$ & 不 可 \\
\hline 11 & 18 & M & 後方脱臼 & 1 力月 & 5 力月 & 観血的整復術 & 不 可 \\
\hline 12 & 25 & M & 後方脱臼 & 1 力月 2 週 & 3 力月 & 観血的整復術 & 不 可 \\
\hline 13 & 37 & $\mathrm{~F}$ & 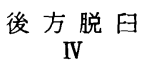 & 20日 & 2 力月 & 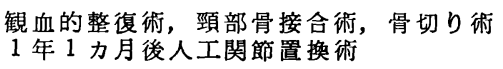 & 不 可 \\
\hline 14 & 49 & M & 後方脱臼 & & & 人工関節置換術 & 良 \\
\hline 15 & 61 & M & 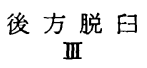 & & & 骨切り術 & 可 \\
\hline 16 & 54 & M & 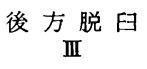 & & & $\begin{array}{l}\text { 骨頭切除術 } \\
\text { 骨切り術 }\end{array}$ & 不 可 \\
\hline
\end{tabular}

鎖骨々折，前腕骨折各々 1 例であり，合併骨折のない むの 6 例であった. 後方脱臼 13 例中 4 例に腓骨神経 麻㾝がみられた（表 1 ).

\section{予 後 調 查}

受傷後平均経過年数 2 年にて，直接検診を行った. 判定はStewart の基準によった. [優】運動制限な し，疼痛なし，X線所見にて特別の変化のないもの.
〔良〕長時間学働または荷重時のみ疼痛があり，跛行 がなく，運動制限は $25 \%$ 以内で 日常生活の障害のな いもの，X線所見にて最少の関節症変化のみ. [可] 軽度の疼痛と跛行があり，25～50％の運動制限およ び歩行能力の低下のあるもの，X線所見にて関節裂隙 の中等度の狭少化, 骨頭に最少の cyst 形成, 臼蓋の 硬化像のあるあの. [不可]疼痛, 跛行があり, 運動 制限著明，X線所見にて関節裂吵狭少，日蓋の硬化像 
著明, 骨頭の avascular necrosis および頸部の著明 な cyst 形成のあるあの. 骨頭の脱臼, 未整復の屯 の. と 4 段階に分類した. 上記の揨断基準により，優 1 例, 良 4 例, 可 4 例, 不可 7 例であり, 可, 不可合 わせて 11 例が不満足のむのであった。 脱臼形式によ る成績は，前方脱臼は良 1 例，可 1 例で，可の例は 6 力月経過した陳旧例であった，中心性脱臼のものは， 12 時間以内に整復され，後に関節内骨片の剔出をし たものであった．後方脱臼 1 度のあのは成績不可が 1 例で，乙れは1 力月後に整復されたものであった，2 度では可 1 例, 不可 1 例で，前者は徒手整復時骨片の 嵌入のあったもの，後者は 6 週後に整復されたもので あった。 3 度では良 1 例，不可 2 例で， 1 例は再脱 曰，1例は整復不能のあのであった４４度では優 1 例，良 1 例，可 2 例，不可 3 例であり， 7 例中 5 例が 不満足の 結果であった. 24 時間以内に 徒手整復され た例は全て満足すべきすので，5日以上経過し徒手整 復困難であったために観血的整復術が施行された 9 例 は，1例を除き全て不満足な結果であった.
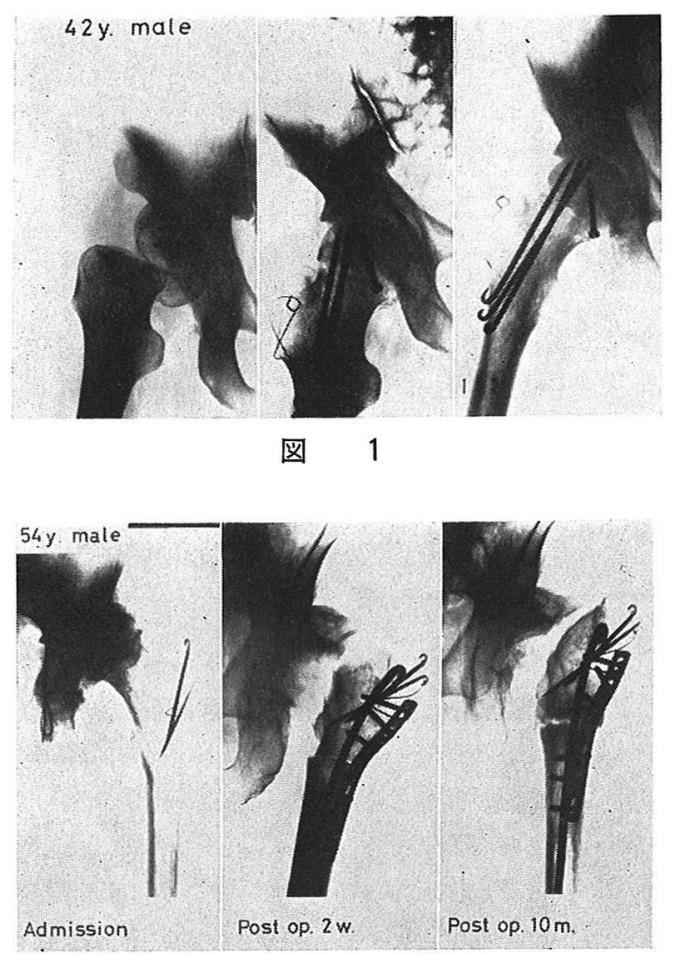

図 2
症

例

症例 1, 52 才, 男性.

乗用車と乗用車の正面衡突により受傷, 後方脱臼 3 度であり，2 日後当科に入院，徒手整復術を受ける む，股関節内転にて容易に亜脱曰するため，鋼線索引 を行い， 2 週後に曰蓋縁の骨接合術施行，術後 8 週に て荷重許可, 受傷後 1 年 9 力月にて総合判定は良であ る。

症例 2,42 才, 男性.

体操中に転倒して受傷，後方脱田 4 度である，近医 にて徒手整復が施行されたが，不成功であり受傷後 8 日目に当科にて観血的整復術および骨頭と頸部の骨接 合術を行う. 免荷 6 力月. 受傷後 6 力月, $X$ 線にて骨 頭の硬化像および運動制限著明にて総合判定は不可で ある。（図 1 )

症例 3,54 才, 男性.

バイク走行中乗用車之衡突し受傷. 大腿開放骨折之 腓骨神経麻瘦を伴っていた，れだちに近医に入院し， 下腿の処置のみを受け，股関節後方脱臼は看過されて いた．受傷後 4 力月目に観血的整復術を試みたが不可 能で, 受傷後 1 年 2 力月で当科に入院し, 骨頭切除と angulation osteotomy を行った. 術後 10 力月の現 在 1 本枚歩行可能であるが，運動制限著明であり，総 合判定は不可である.（図 2 )

総括

外傷性股関節脱F日治療の原則は，続発する二次性 変形性関節症, avascular necrosis 等の合併症を如 何にして防止するかにあるといわれている。乙れらの 不満足な結果をもたらす原因は，外傷の重傷度，脱臼 から整復迄の遅延，他の合併損傷，整復操作のくりか えし，患者年令が大きく影響しているものと思われ る。

よ゙のような合併症を伴っていても，股関節脱臼にお いては即時，整復することが原則であり，又股関節の instability を生じる程の臼蓋縁の骨折を合併してい てあ整復位にあれば目蓋縁の骨折は二次的に内固定を 行えば治療成績に影響を及ぼさないと言われている. われわれが検討した症例中，12 時間以内に徒手整復 された 2 例は，その後骨片の剔出を行ったが総合判定 ではそれぞれ優，良であった。

Stewart 等は脱臼が安定性であれば，整復から全 
面荷重までの期間は最終結果には影響を及ぼさないと 述べている，今回のわれわれの調査においては免荷期 間と成績の間の相互関係は見出だせなかった。

新鮮な外傷性股関節脱臼の内，後方脱臼 1 度の場 合, 非観血的に比較的容易に整復可能であり，比較的 早期に運動性と支持性を回復するあのであるが，早期 に整復を行わなかったために不満足な結果となった症 例ああり, 早期診断, 早期整復の 重要性を示してい た. 後方脱臼 2 度では, 2 例之あ可, 不可之不満足な 成績で，1例は徒手整復により骨片が関節裂隙内に焱 入したもので可であった. 骨片嵌入の臨床症状は不確 実であり，診断はX線撮影によらなければならない. 整復後ただちに両側股関節のX線前後像を撮影し関節 裂隙を比較することが重要である. あし骨片が脱臼の 荷重面に残存するならば, 早期の関節軟骨の破壊と退 行変化をきたし 不満足な結果となることは明白であ る. 他の 1 例は整復の遅延により不可となったと思わ れた。

後方脱臼第 3 度に属するもので, 臼蓋縁の大きい骨 折を伴う, 不安定性のあるものは, Stewart 等は脱 臼を早期整復し, 少なくとあ数日後には臼蓋縁の整復 固定術を施行すべきであると述べている．松原等も股 関節を 90 度屈曲するだけで再脱臼するような症例で は, 骨片の観血的整復固定の絶対的適応とし, また徒 手整復後一応支持性があってあ転位した骨片が $3.0 \times$ $1.5 \mathrm{~cm}$ 以上の時は相対的適応としている. われわれ の 3 症例のうち 2 日目に徒手整復がなされ, 2 週間後 に臼蓋縁の骨接合術を行ったものは良であったが， 2 力月間および 4 力月間放置された 2 例では, 1 例は整 復不能で 1 例は術後再脱臼した.

後方脱臼で大腿骨々頭骨折および頸部骨折を伴う 4 度に属するものは 7 症例であった，大腿骨々頭中心窩 を含まない骨頭骨折 3 症例では 12 時間以内に徒手整 復され，6力月後に骨片剔出を受けた 1 例が優であっ た. 受傷後 11 日目, 7 力月後に観血的整復術および 骨片剔出術を施行されたものは，各々可，不可であっ た. 骨頭粉砕脱臼骨折には一次的に股関節全置換術を 施行した例では 3 年 5 力月後の現在農業に従事してい る. このような脱臼骨折では, 骨頭の損傷の程度, 整 復の容易さ, 骨片の整復の正確さが予後を決定すると 言われる. Stewartは第 4 度で骨頭中心蓇を含む骨折
では,ただちに reconstructive surgery を行うべき だと言っている.

外傷性股関節脱匹に大腿骨頸部骨折を合併した例 は, 特異な大腿骨頭への血行のため脱臼骨頭への血行 は遮断され，しかも脱罒整復は必ず観血的に行わねば ならないため，予後は極めて悪いとされる．高原，

Watson Jones は, 頸部骨折後に発生する avascular necrosis の頻度と脱四後に発生する頻度を考えると， 一次的に reconstuctive surgery を行う方が良いと 述べている，われわれの経験した症例は，観血的整復 術および multiple pinning を施行した. 術後 8 力 月順調に経過しており，avascular necrosis の所見 は認められない。

16 症例中 5 例に変形性股関節症が， 2 例に avascular necrosis が認められた.

坐骨神経損傷については, 後方脱 $\mathrm{EI}$ I, II, III, IV 度に各々 1 例ずつ腓骨経麻㾝を認めた.

結炡

外傷性股関節脱巨更で何らかの観血的治療を要した 16 症例について検討したが，このうち 11 症例が不満 足な成績であった。 乙れは損傷度の高度なものと, 整 復時期の遅延した症例が多かったためと思われる. 股 関節脱臼および脱臼骨折においては早期診断, 早期整 復の重要性を改めて痛感した。

（御指導, 御校閲を賜った恩師宮城成主教授に感謝 の意を表する.）

\section{参考文 献}

1) Brav, E. A.: J. Bone Jt. Surg., 44-A, 1115, 1962.

2) Epstein, H. C.: J. Bone Jt. Surg., 43-A : 1079, 1961.

3) Epstein, H. C.: J. Bone Jt. Surg., 56-A : $1103,1974$.

4）松原統：日整会誌, 44:995, 1970.

5) Stewart, M. J. and Milford, M. D. : J. Bone Jt. Surg., 36-A : 315, 1954.

6) Stewart, M. J. et al. : Acta orthop. Scand., $46: 507,1975$.

7) 高原伸雄ほ加: 災害医学, 14:728, 1971.

8) Watson-Jones, R.: Fractures and Joint Injuries. 2: 664, 1955. 